2013-09-02

\title{
Assessing the Benefits of Compressed Air Energy Storage on the 2020 Irish Power System
}

\author{
Brendan Cleary \\ Technological University Dublin, brendan.cleary1@mydit.ie \\ Aidan Duffy \\ Technological University Dublin, aidan.duffy@tudublin.ie \\ Alan O'Connor \\ Trinity College, alan.oconnor@tcd.ie
}

See next page for additional authors

Follow this and additional works at: https://arrow.tudublin.ie/dubencon2

Part of the Power and Energy Commons

\section{Recommended Citation}

Cleary, B., Duffy, A., O'Connor A., Conlon, M., \& Fthenakis, V. (2013). Assessing the economic benefits of compressed air energy storage on the 2020 Irish Power System. 48th Universities Power Engineering Conference, Dublin, Ireland, 5-6, September.

This Conference Paper is brought to you for free and open access by the Dublin Energy Lab at ARROW@TU Dublin. It has been accepted for inclusion in Conference Papers by an authorized administrator of ARROW@TU Dublin. For more information, please contact arrow.admin@tudublin.ie, aisling.coyne@tudublin.ie, gerard.connolly@tudublin.ie.

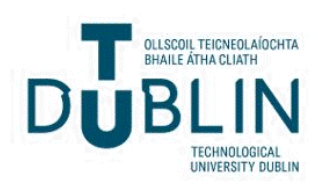




\section{Authors}

Brendan Cleary, Aidan Duffy, Alan O'Connor, Michael Conlon, and Vasilis Fthenakis 


\section{Assessing the benefits of compressed air energy storage on the 2020 Irish Power System}

\author{
Brendan Cleary \\ School of Civil and Building \\ Services Engineering and \\ Dublin Energy Lab, Dublin \\ Institute of Technology, Bolton \\ St., Dublin 1, Ireland \\ brendan.cleary1@mydit.ie \\ Michael Conlon \\ School of Electrical \\ Engineering Systems and \\ Dublin Energy Lab, Dublin \\ Institute of Technology, Kevin \\ St., Dublin 4, Ireland \\ michael.conlon@dit.ie
}

\author{
Aidan Duffy \\ School of Civil and Building Services \\ Engineering and Dublin Energy Lab, \\ Dublin Institute of Technology, \\ Bolton St., Dublin 1, Ireland \\ aidan.duffy@dit.ie
}

Vasilis Fthenakis

Center for Life Cycle Analysis,

Columbia University, 500 W. 120th

St., \#918 Mudd, New York, NY

10027, USA

vmf5@columbia.edu

\author{
Alan O'Connor \\ Department of Civil, Structural \\ and Environmental Engineering, \\ Trinity College, Dublin 2, \\ Ireland \\ alan.oconnor@tcd.ie
}

\begin{abstract}
Power systems have evolved as countries implement energy policies focusing on energy efficiency and increased share of renewable energy sources (RES). At the forefront is nondispatchable generation such as wind and solar. Traditionally power systems were designed for fully dispatchable generating plant. However, these powers systems are under additional pressure due to the variable operational characteristics of RES. Consequently, capital investments in grid reinforcement, interconnection, additional gas generators and smart grid initiatives have been proposed and implemented. Moreover, an increased interest in energy storage technologies has evolved due to their various economic and operational benefits to power systems. Current compressed air energy storage (CAES) plants have shown economic feasibility and reliability. Thus, the main focus of this paper is to investigate and compare two scenarios; one without CAES and a second with CAES as an additional generator in the 2020 Irish power system using power systems simulation software PLEXOS.
\end{abstract}

Index Terms-- $\mathrm{CO}_{2}$ Emissions, Compressed Air Energy Storage Energy Market, PLEXOS, Power System Economics, Power System Operation, Power System Modelling, Revenue, Total Generation Costs, Wind Power

\section{INTRODUCTION}

The utilisation of renewable energy sources (RES), namely non-dispatchable generation such as wind and solar has grown rapidly as countries worldwide strive to meet binding renewable energy targets.

Record installations in the United States (US) and Europe has led to a global capacity of $45 \mathrm{GW}$ of new wind power in 2012, a $10 \%$ increase relative to 2011 [1]. This is driven by the trend of rising costs of fossil fuels along with government policies such as the European Commission's Renewables Directive 2009/28/EC and SET-Plan [2], [3].

Moreover, most European Union Member States have set ambitious targets for increased renewable energy penetration within their electricity markets. In particular the governments of the Republic of Ireland (ROI) and Northern Ireland (NI) have set a target that requires $40 \%$ of generation to come from RES, mainly wind, by 2020 [4].

The ROI and NI will potentially be seeking to operate over $6,000 \mathrm{MW}$ (circa. $39 \%$ of the total generation capacity) of wind farms on the combined, All-Island of Ireland (AII) power system by 2020 [5]. The increasing amount of wind farms due for connection to the AII power system introduces a new challenge for the transmission system operator. This involves maximising the integration and use of the wind power (up to $75 \%$ of installed wind capacity) while maintaining high levels of reliability and security of the system. Moreover, this introduces a number of technical and economic issues, primarily due to the random nature of wind [6].

Subsequently, the ability to store and integrate wind power using large scale energy storage is increasingly being scrutinized as a viable option to overcome these issues [7].

Developing cost effective energy storage technologies is one of the greatest engineering challenges, although the issue has received relatively modest mainstream attention or support compared to wind or solar technologies.

Pre-2020 AII policy has resulted in plans for grid reinforcement, interconnection and additional gas generators [8]. A number of policy commissioned studies have considered the use of large scale energy storage such as pumped hydroelectric energy storage (PHES) and compressed energy storage (CAES) but the benefits they provide to the AII system have not been fully examined [9].

Although, current CAES plants have shown economic feasibility and reliability, economic uncertainties surrounding this technology are still relatively high and further analysis is required. Moreover, CAES may add value to the AII system due to its ability to displace less flexible and more expensive generators. However, questions remain about the economic 
feasibility of CAES in terms of investment cost, as well as its effects on the AII system in terms of providing ancillary services [10].

Thus, the purpose of this paper is to investigate and compare two scenarios; one without CAES and a second with CAES as an additional generator in the 2020 AII system. The main areas investigated were CAES operation and generation, emissions and economic assessments.

\section{COMPRESSED AIR ENERGY STORAGE}

\section{A. Overview of technology}

CAES is a hybrid form of storage and is a modification of the conventional gas turbine (GT) technology. A CAES plant consists of a power train motor that drives a compressor to compress air into a cavern, a high pressure turbine, a low pressure turbine and a generator as shown in Fig. 1.

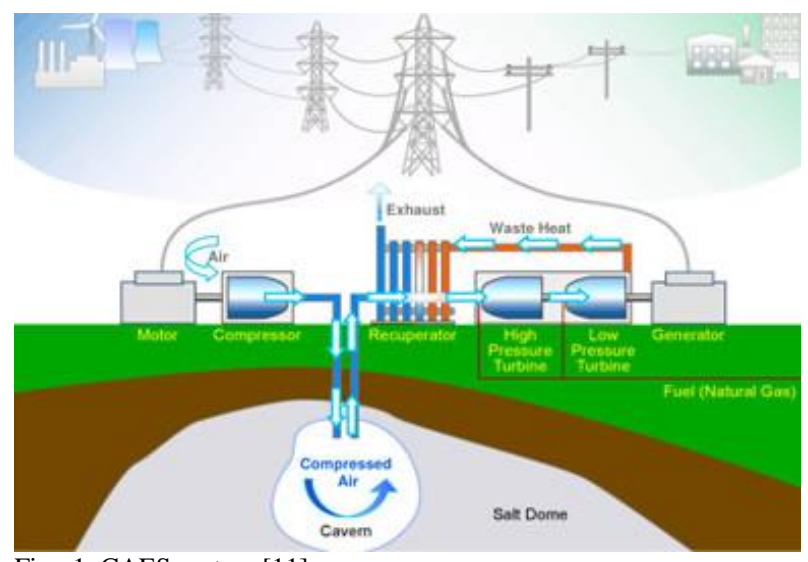

Fig. 1. CAES system [11]

CAES plants operate similarly to a conventional GT except that compression and expansion operations occur independently and at different time periods. During the compression operation, off peak low cost electricity is used to run a chain of compressors which injects air into the cavern.

During the expansion operation, for generating peak high cost electricity, air is withdrawn from the cavern. The pressurised air is then used to power the GT for electricity generation using just $33 \%$ of the gas normally required [12].

However, current CAES plants require large underground caverns and hence, are dependent on geographical location which can be a major disadvantage when planning the use of this storage technology. It can be sometimes difficult to identify underground caverns where CAES plants can be constructed as it needs to be close to the electric grid and gas infrastructure [13]. Moreover, the underground geologies most suitable for constructing CAES caverns are: salt, hard rock and porous rock.

\section{B. Review of research and development}

The technological idea of CAES is more than 40 years old and in the 1970s the first investigation of its feasibility started as a means to provide energy during peak demand and transition time needed from base load plant to reach its operational point [14].
At present, there are two first generation CAES plants in operation, one in Huntorf, Germany where a 290MW plant was constructed in 1978 and another in Alabama, USA where a 110MW plant was constructed in 1991 [7]. Some pilot CAES plants have been built in Japan, Italy (25MW) and the US. Plants have been also proposed for Israel and Russia. In Europe, the idea of developing CAES is obtaining momentum due to the utilisation of intermittent wind and solar power plants.

In particular, an appraisal of the geological conditions and the potential of underground gas storage and CAES technologies was undertaken in Larne, NI [15]. Results indicated that Larne is the only place in NI and one of few places in the United Kingdom, which has salt deposits potentially suitable for CAES [15], [16]. The potential exists for a 268MW CAES plant to be connected to AII power system [16]. Currently, SONI (NI grid operator) is in discussions with a renewables development company about the connection of a proposed CAES plant in the Larne area [17].

Although the use of CAES is not widespread, a significant amount of research has increasingly analysed CAES as a solution to improving wind integration and reducing wind curtailment [7], [18], [19]. A study of a 190MW wind farm located in Victoria, Australia found that CAES was the most profitable storage option with a rate of return of $15.4 \%$ relative to $9.6 \%$ and $8.0 \%$ for PHES(with seawater) and thermal energy storage respectively [20].

A number of techno-economic studies of the AII power system have been undertaken which consider PHES and CAES as additional generators [10], [19], [21]. According to Nyamdash et al. [19] due to the absence of any support mechanisms none of the storage devices were economically viable when combined with wind generation. Lobera et al. [10] concluded that under the current single electricity market (SEM) rules CAES can optimise energy arbitrage opportunities but the value of ancillary services market worth needs to be determined.

Consequently, the benefits of CAES to the AII system necessitate further investigation in terms of energy arbitrage, ancillary services, reduced emissions and avoided curtailment/constraint management.

\section{METHODOLOGY}

\section{A. Modelling software}

PLEXOS version 6.207 R05 was used to build and run the models developed for this analysis. PLEXOS is a power systems modelling tool developed by Energy Exemplar and is used for electricity market modelling and planning worldwide [22]. Since 2007, PLEXOS has been used in Ireland by the Commission for Energy Regulation (CER) and market participants to validate and forecast SEM outcomes. It has also been used for several AII case studies [23-26].

The software was chosen because it provides a flexible interface allowing user defined characteristics and constraints to be assigned 
clearly. Moreover, it is a well proven and robust software which is suitable for examining the AII power system.

\section{B. Model description}

The CER publishes a validated PLEXOS model annually consisting of the technical details for all the generators such as maximum and minimum generation levels, ramp rates and heat rates. The CER validated forecast model of 2011-2012 was used as a starting point from which the 2020 model for this analysis was developed [27].

The 2020 model was populated with the individual generator technical characteristics and the ranges of reserve provision were assigned as per the transmission constraint groups (TCGs) requirements [28]. The system demand and installed wind power capacities for 2020 were obtained from the Eirgrid All-Island generation capacity statement 2012-2021 [29]. The Great Britain (GB) market and interconnections to the ROI and NI were modelled as per the 2011 CER model.

Concurrently the PLEXOS software simulates and optimises the half hourly dispatch of the generation portfolio to meet demand at least cost while taking into account the generators technical and commercial characteristics. Prior to dispatch, PLEXOS calculates the availability of each generator throughout the year while taking into account the planned and unplanned maintenance. The former is assigned manually based on the 2011 schedule and the latter is modelled as a random event.

Similar to the SEM, PLEXOS calculates a system marginal price (SMP) and a generator output schedule for each period, therefore providing an accurate representation of the dispatch of generators on the AII power system. Further details in relation to the model setup and main assumptions are described in the following sections.

\section{Main model assumptions}

The AII system demand is expected to increase $11 \%$ between 2011 and 2020 based on the median demand forecast by Eirgrid [29]. The median demand forecast is considered to reflect the latest projections for the ROI and NI as a result of the economic environment and has been used for several Irish case studies. Accordingly, the 2011 demand time series profile is linearly scaled to reflect the 2020 median demand forecast.

Wind is modelled in aggregated form, split into the 13 regions. Each region has an associated half hourly profile which represents the wind availability in that region in each half hour, as a percentage of total installed capacity in that region. It is assumed that no more offshore wind will be developed in AII prior to 2020 and the 2020 targets will be met almost entirely by onshore wind. It is assumed that only 25.2MW of installed offshore wind capacity exists from a single wind farm at Arklow Bank, Co.Wicklow, Ireland.

A constraint restricting the amount of wind generation on the AII system for a given period is enforced based a system non-synchronous penetration limit. The constraint ensures that the amount of wind generated, when added to imports, does not exceed $70 \%$ of the sum of system load and exports [30].

The thermal generators for the 2020 model are as per the list of new entrants and retirements which have signed agreements and confirmed dates to connect to the AII power system over the next 10 years as in Table I [29].
TABLE I

THERMAL GENERATORS NEW ENTRANTS AND RETIREMENTS UP TO 2021

\begin{tabular}{|c|c|c|c|}
\hline $\begin{array}{c}\text { PLEXOS } \\
\text { Unit ID }\end{array}$ & Unit Name & $\begin{array}{c}\text { Capacity } \\
\text { (MW) }\end{array}$ & Status \\
\hline ST4-6 & Ballylumford & 510 & Retired \\
\hline GI1-3 & Great Island & 212 & Retired \\
\hline TB1-4 & Tarbert & 594 & Retired \\
\hline Dublin W2E & $\begin{array}{c}\text { Dublin Waste-to- } \\
\text { Energy }\end{array}$ & 72 & $\begin{array}{c}\text { New } \\
\text { entrant }\end{array}$ \\
\hline GI & Great Island & 459 & $\begin{array}{c}\text { New } \\
\text { entrant }\end{array}$ \\
\hline NP & Nore Power & 98 & $\begin{array}{c}\text { New } \\
\text { entrant }\end{array}$ \\
\hline CL & Cuilleen Power & 98 & $\begin{array}{c}\text { New } \\
\text { entrant }\end{array}$ \\
\hline SR & Suir Power & 98 & $\begin{array}{c}\text { New } \\
\text { entrant }\end{array}$ \\
\hline
\end{tabular}

A single gas fired generator was used to represent the GB market. Gas fired generation has been the predominant marginal plant type on the GB system and a high correlation between the cost of gas fired generation (including carbon) and the GB power price has been determined [27]. The GB single gas generator was assigned 12 different heat rates and variable operating and maintenance (VOM) costs.

The Moyle interconnector (MI) links NI to Scotland, meaning that the GB market can influence the SEM. Flows on the MI are largely driven by arbitrage of the relative prices in the two markets. The MI is limited to importing 450MW November-March and 410MW April-October. However, there is uncertainty in relation to the actual maximum import and export capacity of the MI for the foreseeable future due to an undersea cable fault [17]. The new East-West interconnector between the ROI and GB, maximum flow was assumed 500MW both ways and price constraints were based on the MI settings.

The SEM is designed around a single unconstrained marginal pricing structure and the price determined within the SEM ignores transmission and reserve constraints but adheres to generator technical abilities. The 2020 model applies historic Transmission Loss Adjustment Factors (TLAFs) to both no-load and start-up costs in addition to the incremental costs of generators. This follows a revision to the SEM rules and systems that now require this to be incorporated into generators bids [27].

Moreover, transmission and system stability requirements are applied as per the TCGs requirements which provides a more realistic representation of the AII power system in the model [28].

\section{Modelling CAES}

A CAES plant is represented in PLEXOS by an idealised pumped storage (PS) plant and an idealised GT connected by some constraints in order to replicate the operation of the CAES plant. In compression mode the PS plant takes power from the grid to compress air and in generation mode, both the PS plant and GT generate power. This approximation has been adopted previously for other case studies [10], [31]. The details of the CAES plant used for this analysis are shown in Table II and are assumed to represent the plant which will be connected to the AII power system in 2020. 
TABLE II

CAES PLANT TECHNICAL OPERATING DETAILS [11]

\begin{tabular}{|l|c|c|}
\hline \multicolumn{1}{|c|}{ Parameters } & Value & Units \\
\hline Maximum compression & 200 & MW \\
\hline Minimum compression & 60 & MW \\
\hline Startup time for compression & 0.4 & hours \\
\hline Ramp rate for compression & 40 & MW/min \\
\hline Maximum generation & 270 & MW \\
\hline Minimum generation & 67.5 & MW \\
\hline Startup time for generation & 0.33 & hours \\
\hline Ramp rate for generation & 270 & MW/min \\
\hline CAES heat rate & 4.265 & GJ/MWh \\
\hline CAES storage capacity & 3 & GWh \\
\hline Compressing Efficiency & 80 & $\%$ \\
\hline $\begin{array}{l}\text { Energy ratio of compressed air } \\
\text { and fuel }\end{array}$ & $2: 1$ & \\
\hline
\end{tabular}

\section{E. Cost data}

Fuel prices are based on predictions for 2020 from several sources [23], [25], [32-34]. A carbon tax of $€ 30 / \mathrm{t} \mathrm{CO}_{2}$ based on the European Union Emissions Trading Scheme (EU ETS) was applied to fossil fuel burning generators; this was a realistic figure based on the carbon taxes used for previous Irish studies, which ranged between $€ 15 / t$ - €45/t [21], [23], [25], [32], [34-36]. Generator VOM costs were obtained from several sources [32], [35], [37-41] and start costs were derived from historic start costs [27]. Cost data for the CAES plant were based on Thorner et al. [11].

All cost data was normalised to 2020 values using historic consumer price indexes [42] and an assumed average annual inflation rate of $1.5 \%$ between 2011-2020 was applied. The cost data has a direct influence on the SMP and the total generation costs but more importantly it has a direct influence on the dispatch of the different types of generators.

The general approach to date for SEM PLEXOS modelling has been to model wind generation at zero short run marginal cost (fuel and carbon costs equal zero) based on the assumption that it will always run when available, due to its priority dispatch status. Hence, this approach has been adopted for this analysis. Similarly, predictable price takers Peat and Aughinish CHP generators are assigned zero short run marginal cost to ensure they are dispatched fully when available.

\section{F. Limitations of the analysis}

This analysis used a deterministic model as a starting point using a set of main assumptions based on engineering judgment and previous studies. The analysis assumed perfect foresight for wind generation and system demand with no significant rules changes to the SEM or to the broader market by 2020 . The analysis therefore applied the current SEM rules and assumed that the current bidding principles and the methodology for calculating the various cost and revenue streams remained unchanged.

\section{RESULTS AND DISCUSSION}

\section{A. Model Scenarios}

To evaluate the benefits of a CAES plant in 2020 two scenarios are run; one without CAES and a second with CAES as an additional generator in the AII system; in the following sections these are identified as scenarios 1 and 2 respectively. A comparison of the scenario results are presented and discussed in the following sections.

\section{B. CAES operation and generation}

Fig. 2 indicates the half hourly compression and generation cycles of the CAES plant over a typical week. During times of high SMP the CAES plant tends to generate and the opposite generally occurs for low SMP. This suggests that the CAES plant is taking advantage of energy arbitrage opportunities within the SEM as a result of the PLEXOS optimisation.

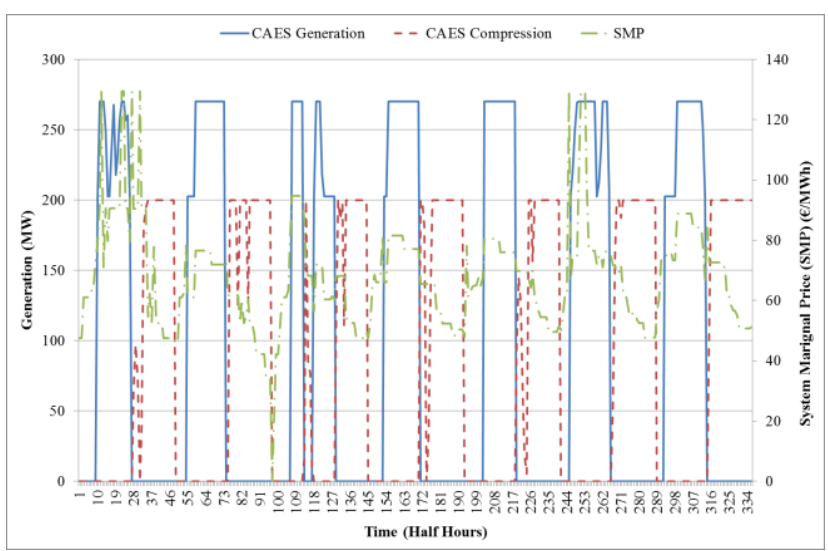

Fig. 2. CAES plant operation

The generation comparison of the two scenarios is presented in Table III. It can be seen there is a decrease in the fossil fuel burning generators namely gas and coal, while there is a minor increase in wind and pumped storage generation. The CAES plant has a generation output of $691 \mathrm{GWh}$ for the entire year offsetting the less flexible and more expensive gas and coal generators. TABLE III GENERATION COMPARISON

\begin{tabular}{|c|c|c|c|c|}
\hline \multirow{2}{*}{ Generators } & \multicolumn{2}{|c|}{ Generation (GWh) } & \multirow{2}{*}{$\begin{array}{c}\text { Difference } \\
\text { (GWh) }\end{array}$} & \multirow{2}{*}{$\begin{array}{c}\text { Difference } \\
(\%)\end{array}$} \\
\hline & Scenario 1 & Scenario 2 & & \\
\hline Gas & 11,802 & 10,417 & -1385.31 & -13.30 \\
\hline Coal & 7,239 & 6,791 & -447.96 & -6.60 \\
\hline Peat & 2,343 & 2,367 & 23.81 & 1.01 \\
\hline Distillate Oil & 3 & 6 & 2.87 & 48.09 \\
\hline Hydro & 1,080 & 1,054 & -25.22 & -2.39 \\
\hline $\begin{array}{l}\text { Pumped } \\
\text { Storage }\end{array}$ & 338 & 353 & 14.72 & 4.17 \\
\hline Wind & 16,049 & 16,286 & 236.91 & 1.45 \\
\hline Wave & 387 & 386 & -1.04 & -0.27 \\
\hline Waste & 654 & 660 & 5.77 & 0.87 \\
\hline Great Britain & 2,812 & 2,842 & 30.20 & 1.06 \\
\hline CAES & - & 691 & - & - \\
\hline
\end{tabular}




\section{Emissions assessment}

A comparison of the tonnes of carbon dioxide $\left(\mathrm{CO}_{2}\right)$ emissions is presented in Table IV. The $\mathrm{CO}_{2}$ emissions for the gas and coal generators have decreased for scenario 2 relative to scenario 1 . The CAES plant's $\mathrm{CO}_{2}$ emissions are included with the gas generators for scenario 2. The peat and distillate oil generators $\mathrm{CO}_{2}$ emissions have increased by $1 \%$ and $43 \%$ respectively.

Overall, the AII system total tonnes of $\mathrm{CO}_{2}$ emissions have decreased by $9.05 \%$ due to the addition of the CAES plant in the AII system. $\quad \mathrm{A} \mathrm{CO}_{2}$ emissions target level of 12.3 million tonnes for electricity generation in 2020 [43] is met as both scenarios give emissions below this threshold.

TABLE IV

CARBON EMISSIONS COMPARISON

\begin{tabular}{|l|c|c|c|c|}
\hline \multirow{2}{*}{ Generators } & \multicolumn{2}{|c|}{ Emissions (tCO2) } & \multirow{2}{*}{$\begin{array}{c}\text { Difference } \\
\text { (tCO2) }\end{array}$} & $\begin{array}{c}\text { Difference } \\
\text { (\%) }\end{array}$ \\
\cline { 2 - 3 } & Scenario 1 & Scenario 2 & \\
\hline Gas & $3,461,003$ & $3,037,652$ & $-423,351$ & -13.94 \\
\hline Coal & $7,303,486$ & $6,804,927$ & $-498,559$ & -7.33 \\
\hline Peat & 248,409 & 250,934 & 2,524 & 1.01 \\
\hline $\begin{array}{l}\text { Distillate } \\
\text { Oil }\end{array}$ & 6,581 & 11,579 & 4,999 & 43.17 \\
\hline & & & & \\
\hline Total & $11,019,479$ & $10,105,092$ & $-914,387$ & -9.05 \\
\hline
\end{tabular}

Similarly, the $\mathrm{CO}_{2}$ emissions produced for fossil fuel burning generators have decreased slightly for scenario 2 relative to scenario 1 as presented in Table $\mathrm{V}$.

TABLE V

CARBON EMISSIONS PRODUCTION COMPARISON

\begin{tabular}{|l|c|c|c|c|}
\hline \multirow{2}{*}{ Generators } & \multicolumn{2}{|c|}{$\begin{array}{r}\text { Emissions production } \\
\text { (gCO2/kWh) }\end{array}$} & $\begin{array}{c}\text { Difference } \\
\text { (gCO2/kWh) }\end{array}$ & $\begin{array}{c}\text { Difference } \\
(\%)\end{array}$ \\
\cline { 2 - 3 } & Scenario 1 & Scenario 2 & & \\
\hline Gas & 293 & 273 & -20 & -7.24 \\
\hline Coal & 1,009 & 1,002 & -7 & -0.69 \\
\hline Peat & 106 & 106 & 0 & 0.00 \\
\hline $\begin{array}{l}\text { Distillate } \\
\text { Oil }\end{array}$ & 2,122 & 1,938 & -184 & -9.47 \\
\hline & & & & \\
\hline Total & 3,530 & 3,320 & -210 & -6.33 \\
\hline
\end{tabular}

\section{Economic assessment}

A comparison of the pool revenues is presented in Table VI. The pool revenue (price received $\mathrm{x}$ generation) is the revenue collected by each generator in the SEM. It can be seen that due to the addition of the CAES plant, the pool revenues for most of the generators increase. This is mainly due to an increase in the average annual price received from $€ 90 / \mathrm{MWh}$ to $€ 117 / \mathrm{MWh}$ as a result of the CAES plant's inclusion in the generation portfolio. However, the gas generators which represent a large portion of the overall generation portfolio do not benefit from the CAES plant's inclusion.

This is beneficial to most of the power producers but it has a negative effect on the retail market. The power producers are paid a higher price from the pool which then has a knock-on effect to the electricity consumer.

TABLE VI POOL REVENUES COMPARISON

\begin{tabular}{|c|c|c|c|c|}
\hline \multirow{2}{*}{ Generators } & \multicolumn{2}{|c|}{ Pool Revenue (€000) } & \multirow{2}{*}{$\begin{array}{l}\text { Difference } \\
\quad(€ 000)\end{array}$} & \multirow{2}{*}{$\begin{array}{c}\text { Difference } \\
(\%)\end{array}$} \\
\hline & Scenario 1 & Scenario 2 & & \\
\hline Gas & $1,127,036$ & $1,132,758$ & $5,721.55$ & 0.51 \\
\hline Coal & 617,194 & 641,866 & $24,671.50$ & 3.84 \\
\hline Peat & 170,690 & 199,430 & $28,740.16$ & 14.41 \\
\hline Distillate Oil & 459 & 1,263 & 804.04 & 63.64 \\
\hline Hydro & 83,365 & 91,497 & $8,132.09$ & 8.89 \\
\hline $\begin{array}{l}\text { Pumped } \\
\text { Storage }\end{array}$ & 25,933 & 26,004 & 70.49 & 0.27 \\
\hline Wind & $1,124,424$ & $1,408,525$ & $284,101.53$ & 20.17 \\
\hline Wave & 28,242 & 33,684 & $5,442.08$ & 16.16 \\
\hline Waste & 53,338 & 62,400 & $9,061.86$ & 14.52 \\
\hline CAES & - & 87,594 & - & - \\
\hline
\end{tabular}

Table VII presents the total generation cost (including VOM cost, fuel cost and emissions costs); compression cost; pool revenue and net revenue (the revenue collected in the energy market minus the total generation cost and compression cost) for the CAES plant over the year 2020. Additional revenues for the CAES plant include reserve revenue from the ancillary services market and annual capacity payments. This analysis has not taken these additional revenues into account due to the uncertainty of how CAES will participate in the SEM under current market rules.

$$
\text { TABLE VI I }
$$

CAES COSTS AND REVENUES

\begin{tabular}{|l|c|}
\hline \multicolumn{1}{|c|}{ Item } & Value (€000) \\
\hline Total generation cost & 13,298 \\
\hline Compression cost & 40,495 \\
\hline Pool revenue & 87,594 \\
\hline Net Revenue & 33,801 \\
\hline
\end{tabular}

The CAES plant receives positive net revenue of $€ 33,801,000$ over the year 2020; research is in progress to determine the additional revenue gained from the ancillary services market and 
annual capacity payments. This is of particular interest to an investor as CAES is a capital intensive technology and a detailed cost benefit analysis would help determine whether it is a viable technology.

\section{CONCLUSION}

The potential benefits of CAES to the 2020 AII system were evaluated by using the power systems and market modelling tool PLEXOS. Based on the modelling conducted, it was determined that a 270MW CAES plant can displace a significant fraction of coal and natural gas generators. The CAES plant has a minor effect on wind generation and this presumable due to the large system non-synchronous penetration limit in 2020. However, it would be interesting to examine the effect on the AII system if wind was modelled stochastically relative to perfect foresight.

The addition of a 270MW CAES plant in the AII system enables a $9.05 \%$ reduction of $\mathrm{CO}_{2}$ emissions. Also, due to the addition of CAES, the pool revenues for most of the generators increased. Although, this is beneficial to most of the power producers it has a negative effect on the retail market.

Furthermore, CAES can achieve a high positive net revenue under current SEM rules while exploiting energy arbitrage opportunities. However, it remains for continuing research to study the additional revenue to be gained from the ancillary services market and annual capacity payments.

\section{ACKNOWLEDGEMENTS}

The author would like to express his appreciation to Dublin Institute of Technology for funding this research through the Fiosraigh Dean of Graduate Research School Award 2011. Furthermore, the author would like to express his gratitude to Energy Exemplar for providing an academic licence for PLEXOS.

\section{REFERENCES}

[1] GWEC, “Annual market update 2011,” 2012.

[2] European Parliament, Directive 2009/28/EC of the European Parliament and of the council of the European Union on the promotion of the use of energy from renewable sources. European Parliament, 2009, pp. 16-62.

[3] T. Secretariat, "Wind European Industrial Initiative Team 2010 - 2012 Implementation Plan," 2010.

[4] E. and N. R. Department of Communications and National, "National Renewable Energy Action Plan," 2009.

[5] I. M. Dudurych, J. O'Sullivan, A. Rogers, D. Bell, S. Rourke, and N Kamaluddin, "Tools for handling high amounts of wind generation in National Control Centre in Ireland," 2012 IEEE Power and Energy Society General Meeting, pp. 1-8, Jul. 2012.

[6] A. M. Foley, B. P. Ó Gallachóir, E. J. McKeogh, D. Milborrow, and P. G. Leahy, "Addressing the technical and market challenges to high wind power integration in Ireland," Renewable and Sustainable Energy Reviews, vol. 19, pp. 692-703, Mar. 2013

[7] A. Evans, V. Strezov, and T. J. Evans, "Assessment of utility energy storage options for increased renewable energy penetration," Renewable and Sustainable Energy Reviews, vol. 16, no. 6, pp. 4141-4147, Aug. 2012.

[8] Eirgrid, "Grid 25 A Strategy for the Development of Irelands Electricity Grid for a Sustainable and Competitive Future," 2010.

[9] A. M. Foley, "The Challenges , Barriers and Opportunities to Integrating Wind Power in the All Island Grid using Energy Storage," 2011.

[10] I. D. Lobera and A. Foley, "Modelling Gas Storage with Compressed Air Energy Storage in a System with Large Wind Penetrations," in 7th Conference on Sustainable Development of Energy, Water and Environment Systems, 2012.
T. Thorner, S. Pratt, S. Green, S. Weaver, S. Gonzalez, and A. Lau, "The Economic Impact of CAES on Wind in TX , OK, and NM," 2005. EPRI-DOE, "Handbook of Energy Storage for Transmission \& Distribution Applications," Palo Alto, CA, Washington, 2003.

[13] D. Connolly, "A Review of Energy Storage Technologies For the integration of fluctuating renewable energy," 2010.

I. Glendenning, "Long-term prospects for compressed air storage," Applied Energy, vol. 2, no. 1, pp. 39-56, Jan. 1976.

[15] D. J. Evans, D. M. Reay, N. J. Riley, W. I. Mitchell, and J. Busby, "Appraisal of underground energy storage potential in Northern Ireland," 2006

Gaelectric Energy Storage, "Larne." [Online]. Available: http://www.gaelectric.ie/index.php/energy-storage/larne/. [Accessed: 03May-2013].

[17] Eirgrid \& SONI, “All-Island Generation Capacity Statement 2013-2022," 2013.

[18] R. Loisel, A. Mercier, C. Gatzen, N. Elms, and H. Petric, "Valuation framework for large scale electricity storage in a case with wind curtailment," Energy Policy, vol. 38, no. 11, pp. 7323-7337, Nov. 2010.

[19] B. Nyamdash, E. Denny, and M. O'Malley, "The viability of balancing wind generation with large scale energy storage," Energy Policy, vol. 38, no. 11, pp. 7200-7208, Nov. 2010.

M.-A. Hessami and D. R. Bowly, "Economic feasibility and optimisation of an energy storage system for Portland Wind Farm (Victoria, Australia)," Applied Energy, vol. 88, no. 8, pp. 2755-2763, Aug. 2011.

[21] A. Tuohy and M. O'Malley, "Pumped storage in systems with very high wind penetration," Energy Policy, vol. 39, no. 4, pp. 1965-1974, Apr. 2011. wind penetration," Energy Policy, vol. 39, no. 4, pp. 1965-1974, Apr. 2011.
E. Exemplar, "PLEXOS $₫$," 2013. [Online]. Available: http://www.energyexemplar.com/. [Accessed: 31-Jan-2013].

A. Foley, B. Tyther, P. Calnan, and B. Ó Gallachóir, "Impacts of Electric Vehicle charging under electricity market operations," Applied Energy, vol. 101, pp. 93-102, Jan. 2013.

[24] E. V. Mc Garrigle, J. P. Deane, and P. G. Leahy, "How much wind energy will be curtailed on the 2020 Irish power system?," Renewable Energy, vol 55, pp. 544-553, Jul. 2013.

[25] J. P. Deane, G. Dalton, and B. P. Ó Gallachóir, "Modelling the economic impacts of 500MW of wave power in Ireland," Energy Policy, vol. 45, pp. 614-627, Jun. 2012.

p. $1914-1924$, Man 2009 . CER, "Validation of Market Simulation Software in SEM to end 2012," Dublin, 2011

Eirgrid \& SONI, "Transmission Constraint Groups," 2012.

Eirgrid \& SONI, "All-Island Generation Capacity Statement 2012-2021," Dublin, 2012.

CER, "Treatment of Curtailment in Tie-break Situations," 2013.

M. Ni, Z. Zhou, and D. Osbo, "Economic and operation benefits of energy storage - a case study at MISO," IEEE, pp. 1-7, 2012.

D. Connolly, H. Lund, B. V. Mathiesen, and M. Leahy, "Modelling the existing Irish energy-system to identify future energy costs and the maximum wind penetration feasible," Energy, vol. 35, no. 5, pp. 2164-2173, May 2010.

Eirgrid, "Executive Summary: Interconnection economic feasibility report," no. November, 2009.

[34] E. Phillips, "The impact of wind on pricing within the Single Electricity Market," no. February, 2011

[35] R. Doherty, H. Outhred, M. O. Malley, and S. Member, "Establishing the Role That Wind Generation May Have in Future Generation Portfolios," vol. 21, no. 3, pp. 1415-1422, 2006.

[36] A. Tuohy, M. Bazilian, R. Doherty, B. Ó. Gallachóir, and M. O’Malley, "Burning peat in Ireland: An electricity market dispatch perspective," Energy Policy, vol. 37, no. 8, pp. 3035-3042, Aug. 2009.

[37] A. Arapogianni, G. Rodrigues, N. Fichaux, A. Zervos, and G. Caralis, "Model For Comparing And Projecting The Levelised Cost Of Electricity Generated By New Gas, Coal, Nuclear Power Stations And Wind Energy ( On- And Offshore )," in Wind Energy, 2009, pp. 1-12.

[38] Mott MacDonald, "UK Electricity Generation Costs Update," Brighton, Mott

[39] G. Allan, M. Gilmartin, P. McGregor, and K. Swales, "Levelised costs of Wave and Tidal energy in the UK: Cost competitiveness and the importance of 'banded' Renewables Obligation Certificates," Energy Policy, vol. 39, no. 1, pp. 23-39, Jan. 2011

[40] D. J. Swider and C. Weber, "An electricity market model to estimate the marginal value of wind in an adapting system," IEEE, p. 8 pp., 2006.

D. of T. and Industry, "Overview of Modelling of the Relative Electricity Generating Costs of Different Technologies," 2006

[42] C. S. Office, "Annual percentage change of consumer price index," 2013. [Online]. Available: http://www.cso.ie/quicktables/GetQuickTables.aspx?FileName=CPA01C3.a sp $\&$ TableName $=$ Annual + Percentage + Change $\&$ StatisticalProduct $=$ DB $C P$ CER, "Impact of High Levels of Wind Penetration in 2020 on the Single Electricity Market ( SEM )," 2009. 